\title{
GAMBARAN ENZIM HATI PADA DEWASA MUDA DENGAN OBESITAS SENTRAL
}

\author{
${ }^{1}$ Friedly Pondaag \\ ${ }^{2}$ Emma Moeis \\ ${ }^{2}$ Bradley Waleleng \\ ${ }^{1}$ Kandidat Skripsi Fakultas Kedokteran Universitas Sam Ratulangi Manado
${ }^{2}$ Bagian Penyakit Dalam BLU RS Prof. Dr. R.D Kandou Manado
Email: friedlycalvino@yahoo.com
}

\begin{abstract}
Absract: Obesity can be defined as excess body fat. Obesity is most commonly caused by a combination of excessive food energy intake. Central obesity has been characterized by waist circumference using the Asia Pasific criteria in males $>0 \mathrm{~cm}$ and $\geq 80 \mathrm{~cm}$ in females. This study aims to look the description of liver enzymes in central obesity in young adults age 18 to 21 years old. Samples were 30 persons with central obesity. Examination of samples taken in the levels of SGOT (Serum Glutamic Oxaloacetic Transaminase) and SGPT (Serum Glutamic Piruvic Transaminase) with normal values 5-40 IU/L for SGOT and 5-35 IU/L for SGPT. The results showed elevated levels of SGOT and SGPT in men, whereas in female respondents didn't showed any elevation in SGOT and SGPT levels.
\end{abstract}

Keywords: central obesity, SGOT, SGPT.

\begin{abstract}
Abstrak: Obesitas dapat didefinisikan sebagai kelebihan lemak tubuh. Obesitas disebabkan oleh pemasukan jumlah makanan yang lebih besar daripada pemakaiannya oleh tubuh sebagai energi. Obesitas sentral ditandai dengan lingkar perut (LP) berdasarkan kriteria Asia Pasifik pada laki-laki lingkar perut $\geq 90 \mathrm{~cm}$ dan perempuan lingkar perut $\geq 80 \mathrm{~cm}$. Penelitian ini bertujuan untuk melihat gambaran enzim hati dengan obesitas sentral pada dewasa muda umur 18 sampai 21 tahun. Penelitian ini bertujuan untuk melihat gambaran enzim hati dengan obesitas sentral pada golongan umur 18 sampai 21 tahun. Sampel berjumlah 30 orang yang tergolong obesitas sentral. Pemeriksaan sampel yang dilakukan adalah kadar SGOT (Serum Glutamic Oxaloacetic Transaminase) dan SGPT (Serum Glutamic Piruvic Transaminase) dengan nilai normal 5-40 IU/L untuk SGOT dan 5-35 IU/L untuk SGPT. Hasil yang didapat menunjukkan peningkatan kadar SGOT dan SGPT pada pria, sedangkan pada responden wanita tidak mengalami peningkatan kadar SGOT dan kadar SGPT
\end{abstract}

Kata kunci: obesitas sentral, SGOT, SGPT.

Obesitas disebabkan oleh pemasukan jumlah makanan yang lebih besar daripada pemakaiannya oleh tubuh sebagai energi. ${ }^{1}$ Obesitas telah mencapai proporsi epidemi global, dengan sedikitnya 2,8 juta orang meninggal setiap tahun sebagai akibat dari kelebihan berat badan atau obesitas. ${ }^{2}$ Kelebihan berat badan dan obesitas didefinisikan sebagai akumulasi lemak abnormal atau berlebihan yang menyajikan risiko bagi kesehatan. ${ }^{3}$ Obesitas merupakan suatu penyakit multifaktorial, yang terjadi akibat akumulasi jaringan lemak berlebihan sehingga dapat mengganggu kesehatan. ${ }^{4}$ Obesitas dianggap sebagai masalah karena komplikasi yang ditimbulkannya. Menurut World Health Organisation (WHO) masalah kesehatan yang erat kaitannya dengan obesitas sebagai faktor resiko terbesar adalah DM tipe 2, dislipidemia, penyakit metabolik, penyakit jantung koroner, hipertensi, dan osteoarthritis. ${ }^{5}$ Pada Journal 
of Clinical and Diasnostic Research dikatakan bahwa Nonalcoholic steatohepatitis (NASH) dan nonalcoholic fatty liver disease (NAFLD) telah menjadi perhatian para peneliti karena NAFLD ini dianggap sebagai manifestasi sindrom metabolik yang erat kaitannya dengan obesitas. NASH telah menunjukkan bahwa fibrosis dapat berkembang menjadi sirosis. ${ }^{6,7}$

Di Indonesia, data menunjukkan prevalensi status gizi penduduk dewasa $(>18$ tahun) tahun 2010 berdasarkan indeks massa tubuh (IMT) di daerah Sulawesi Utara adalah yang paling tinggi, dimana 21,9\% penduduknya memiliki obesitas, sedangkan Nusa Tenggara Barat merupakan daerah yang paling rendah prevalensi penduduk yang obesitas, hanya 6,5\% dari jumlah penduduknya yang memiliki obesitas. ${ }^{8}$

Indeks massa tubuh (IMT) merupakan indeks sederhana dari berat badan dan tinggi badan yang biasa digunakan untuk mengklasifikasikan kelebihan berat badan dan obesitas pada orang dewasa. Hal ini didefinisikan sebagai berat badan seseorang dalam kilogram dibagi dengan kuadrat tinggi badan dalam meter $\left(\mathrm{kg} / \mathrm{m}^{2}\right){ }^{5}$ IMT merupakan ukuran antropometrik yang paling banyak digunakan untuk mengklasifikasikan berat badan, ${ }^{9}$ meski kadang dapat terjadi misklasifikasi terhadap perhitungan IMT, sebagai contoh para atlit yang memiliki tubuh besar dan berotot dapat memiliki hasil IMT $>25 \mathrm{~kg} / \mathrm{m}^{2}$ karena massa otot lebih berat daripada massa lemak. ${ }^{5}$ Walaupun IMT $<25 \mathrm{~kg} / \mathrm{m}^{2}$, obesitas sentral dapat saja terjadi, sehingga penyesuaian IMT pada keadaan obesitas sentral perlu diperhatikan, terutama bila IMT di antara $22-29 \mathrm{~kg} / \mathrm{m}^{2}$. Sehingga pada penelitian ini, jumlah lemak perut dapat diukur dengan ketepatan yang lebih tinggi melalui pengukuran lingkar pinggang bukan dengan IMT. Ditandai dengan lingkar pinggang memakai kriteria Asia Pasifik pada laki-laki $90 \mathrm{~cm}$ dan perempuan $80 \mathrm{~cm}^{4}$

\section{METODOLOGI PENELITIAN}

Penelitian ini menggunakan desain deskriptif Cross-sectional. Subjek merupakan mahasiswa Fakultas Kedokteran UNSRAT dengan golongan umur 18 sampai 21 tahun dengan obesitas sentral. Penelitian dilakukan selama bulan November 2012. Pengambilan darah intravena dilakukan pada 30 orang subjek dengan obesitas sentral. Hasil penelitian diuji dengan tabel frekuensi.

\section{HASIL PENELITIAN}

Penelitian ini bersifat proposive sampling yang dilakukan pada tanggal 2021 november 2012 untuk mendapatkan dan mengumpulkan data lingkar perut pada mahasiswa Fakultas Kedokteran Universitas Sam Ratulangi pada kelompok umur 18-21 tahun. Pada tanggal 29-30 november 2012 dilaksanakan pengambilan darah sampel di ruang pakar di Fakultas Kedokteran Universitas Sam Ratulangi dan hasil tersebut dibawa ke laboratorium untuk diperiksa kadar SGOT dan SGPT. Pada penelitian ini, peneliti mengambil 30 responden dengan obesitas sentral kelompok umur 18-21 tahun. Sebelum diambil darah 30 responden diharapkan mengisi informed consent.

Pada Tabel karakteristik dibawah dapat diuraikan bahwa terdapat 17 responden pria dan 13 responden wanita dengan golongan umur dari 18 sampai 21 tahun. Hasil pengukuran lingkar pinggang pada responden pria didapatkan $90 \mathrm{~cm}$ untuk nilai minimum dan $107 \mathrm{~cm}$ untuk nilai maksimum, sedangkan pada wanita $82 \mathrm{~cm}$ untuk nilai minimum dan $121 \mathrm{~cm}$ untuk nilai maksimum. Dari hasil pemeriksaan SGOT didapatkan pada pria dengan nilai minimum $14 \mathrm{U} / \mathrm{L}$ dan nilai maksimum $67 \mathrm{U} / \mathrm{L}$, sedangkan pada wanita $10 \mathrm{U} / \mathrm{L}$ untuk nilai minimum dan 29 U/L untuk nilai maksimum. Pada pemeriksaan SGPT didapatkan pada pria dengan nilai minimum $29 \mathrm{U} / \mathrm{L}$ dan nilai maksimum $175 \mathrm{U} / \mathrm{L}$, sedangkan pada wanita $26 \mathrm{U} / \mathrm{L}$ untuk nilai minimum dan 59 U/L untuk nilai maksimum. 
Pondaag, Moeis, Waleleng; Gambaran Enzim Hati pada Dewasa Muda...

Tabel 1. Karakteristik sampel penelitian

\begin{tabular}{|c|c|c|c|c|}
\hline & $\mathrm{N}$ & Minimum & Maximum & Satuan berat \\
\hline $\begin{array}{ll}\text { Umur } & 0 \\
& 0\end{array}$ & $\begin{array}{l}17 \\
13\end{array}$ & $\begin{array}{l}18 \\
18\end{array}$ & 21 & tahun \\
\hline $\begin{array}{ll}\text { Jenis kelamin } & \hat{\delta} \\
& +\end{array}$ & $\begin{array}{l}17 \\
13\end{array}$ & & & orang \\
\hline Lingkar pinggang ${ }^{\top}$ & $\begin{array}{l}17 \\
13\end{array}$ & $\begin{array}{l}90 \\
82\end{array}$ & $\begin{array}{l}107 \\
121\end{array}$ & $\mathrm{~cm}$ \\
\hline SGOT & $\begin{array}{l}17 \\
13\end{array}$ & $\begin{array}{l}14 \\
10\end{array}$ & $\begin{array}{l}67 \\
29\end{array}$ & $\mathrm{U} / \mathrm{L}$ \\
\hline SGPT & $\begin{array}{l}17 \\
13\end{array}$ & $\begin{array}{l}29 \\
26\end{array}$ & $\begin{array}{c}175 \\
59\end{array}$ & $\mathrm{U} / \mathrm{L}$ \\
\hline
\end{tabular}

Tabel 2. Distribusi kadar SGOT dan SGPT berdasarkan kelompok umur pada pria dengan obesitas sentral

\begin{tabular}{c|c|c|c|c|c}
\hline \multirow{2}{*}{$\begin{array}{c}\text { Umur } \\
\text { (tahun) }\end{array}$} & \multirow{2}{*}{$\mathrm{N} / \%$} & \multicolumn{2}{|c|}{ Kadar SGOT } & \multicolumn{2}{c}{ Kadar SGPT } \\
\cline { 3 - 6 } & & Normal & Abnormal & Normal & Abnormal \\
\hline 18 & $3(17,65 \%)$ & 2 & 1 & 2 & 1 \\
19 & $6(35,29 \%)$ & 6 & - & 3 & 3 \\
20 & $7(41,18 \%)$ & 7 & - & 4 & 3 \\
21 & $1(5,88 \%)$ & 1 & - & 1 & - \\
\hline Total & $17(100 \%)$ & 16 & 1 & 10 & 7 \\
\hline
\end{tabular}

Tabel 3. Distribusi kadar SGOT dan SGPT berdasarkan kelompok umur pada wanita dengan obesitas sentral

\begin{tabular}{c|c|c|c|c|c}
\hline \multirow{2}{*}{$\begin{array}{c}\text { Umur } \\
\text { (tahun) }\end{array}$} & \multirow{2}{*}{ N/\% } & \multicolumn{2}{|c|}{ Kadar SGOT } & \multicolumn{2}{c}{ Kadar SGPT } \\
\cline { 3 - 6 } & & Normal & Abnormal & Normal & Abnormal \\
\hline 18 & $3(23,08 \%)$ & 3 & - & 3 & - \\
19 & $5(38,46 \%)$ & 5 & - & 5 & - \\
20 & $4(30,77 \%)$ & 4 & - & 4 & - \\
21 & $1(7,69 \%)$ & 1 & - & 1 & - \\
\hline Total & $13(100 \%)$ & 13 & - & 13 & - \\
\hline
\end{tabular}

Pada Tabel 2 dapat dilihat dari 3 responden pria yang berumur 18 tahun, terdapat 2 responden yang memiliki kadar SGOT normal dan 1 responden memiliki peningkatan kadar SGOT. Untuk kadar SGPT pada kelompok umur 18 tahun, 2 responden memiliki kadar SGPT normal dan 1 orang memiliki peningkatan kadar SGPT. Pada kelompok umur 19 tahun, 6 responden dengan kadar SGOT normal dan tidak ada yang mengalami peningkatan kadar SGOT. Untuk kadar SGPT terdapat 3 responden dengan kadar SGPT normal dan 3 responden mengalami peningkatan kadar SGPT. Pada kelompok umur 20 tahun tidak ada peningkatan kadar SGOT, tetapi pada kadar SGPT terdapat 3 responden mengalami peningkatan dan 4 responden memiliki kadar SGPT normal. Pada kelompok umur 21 tahun terdapat 1 responden yang tidak mengalami peningkatan kadar SGOT maupun kadar SGPT.

Pada Tabel 3 dapat dilihat 3 responden yang berumur 18 tahun tidak mengalami peningkatan kadar SGOT maupun SGPT. Kelompok umur 19 sampai 21 tahun juga menunjukkan bahwa tidak ada responden 
yang mengalami peningkatan kadar SGOT dan SGPT.

\section{BAHASAN}

Kisaran normal untuk tingkat aminotransferase sedikit lebih tinggi pada laki-laki, etnis, dan obesitas. Sedikit peningkatan kadar SGOT dan kadar SGPT $(<1.5 x)$ tidak selalu menunjukkan adanya penyakit hati. Namun pemeriksaan laboratorium fungsi hati yang normal tidak selalu berarti bahwa hati tidak mengalami gangguan. Hepatitis autoimun, hepatitis B, Hepatitis C, narkotika, etanol, perlemakan hati, cedera otot, gagal jantung kongestif, tumor, penyakit Wilson merupakan penyebab peningkatan kadar SGOT dan kadar SGPT pada pasien asimtomatik. ${ }^{10}$

Salah satu faktor mempengaruhi kadar SGOT dan kadar SGPT pada wanita yaitu hormon estrogen. Dengan tingginya hormon estrogen maka terjadi gangguan pada fungsi hati. ${ }^{1}$ Pil KB diketahui memicu estrogen dalam tubuh meningkat. Dalam penelitian ini tidak terdapat peningkatan kadar SGOT dan kadar SGPT pada wanita dewasa muda karena responden belum menggunakan pil $\mathrm{KB}$ yang bisa meningkatkan estrogen.

\section{SIMPULAN}

Peningkatan kadar SGOT dan SGPT lebih tinggi terjadi pada laki-laki, etnis kulit hitam, dan obesitas. Estrogen merupakan faktor yang mempengaruhi kadar SGOT dan SGPT pada wanita.

\section{UCAPAN TERIMA KASIH}

Ucapan terima kasih disampaikan kepada Prof. Dr. dr Emma Sy. Moeis,SpPD-KGH, dr. B. J. Waleleng,SpPD-KGEH dan kepada semua pihak yang baik secara langsung maupun tidak langsung telah menumbuhkan ide/gagasan dalam pemikiran penulis sehingga dapat menyelesaikan artikel ini.

\section{DAFTAR PUSTAKA}

1. Guyton AC, Hall JE. Buku Ajar Fisiologi Kedokteran edisi 11.EGC. Jakarta. 2007. hal
917,1070

2. World Health Organization. 10 fact on obesity. Switzerland. 2012. Avaiable from: URL: http://www.who.int/features/factfiles/ obesity/en/

3. World Health Organization. Obesity. Switzerland. 2012. Avaiable from: URL: http://www.who.int/topics/obesity/en/

4. Sudoyo AW. Buku Ajar Ilmu Penyakit Dalam. Jilid III Edisi V. Interna Publishing Pusat Penerbitan Ilmu Penyakit Dalam. Jakarta. 2009. hal 1973,1977-1980

5. World Health Organization. The Asia Pasific Perspective : Redefining Obesity and Its Treatment. Switzerland. 2012 Avaiable from: URL: http://www.wpro.who.int/ nutrition/documents/docs/Redefiningobesity .pdf

6. Bertola, A. et al. Hepatic Expression Patterns of Imflammatory and Immune response Genes Associated With Obesity and NASH in Morbidity Obese Patients. 2010. Avaiable from: URL : http://www.plosone.org/article/info

7. Patell R. et al. Journal of Clinical and Diagnostic Research: Non Alcoholic Fatty Liver Disease (NAFLD) in Obesity. India. 2014. Avaiable from: URL: http://www.ncbi.nlm.nih.gov/pmc/articles/P MC3939589/

8. Depkes RI. Profil Data Kesehatan Indonesia. Jakarta. 2011. Avaiable from: URL: http://www.depkes.go.id/downloads/ PROFIL_DATA_KESEHATAN_INDONE SIA_TAHUN_2011.pdf

9. Gibney J.M, Margetts B, Kearney J.M., Arab L. Gizi Kesehatan Masyarakat. EGC. Jakarta. 2009. hal 204-205. Avaiable from: URL: http://books.google.co.id/books? $\mathrm{id}=\mathrm{jGPFU} 8$ SwbAUC\&pg=PA172\&lpg=PA $172 \& d q=$ central+obesity+correlates+with+a n+increased+incidence+ + of +nash/nafld\&sour ce=bl\&ots=OxluEQUWNM\&sig $=$ qmL2EX MaLEMicvDQGuzoZjUDzM\&hl $=$ en\&sa $=X$ \&ei=c6aFU4a1E4_48QWczYKYCg\&ved= 0CIIBEOgBMAk\# $\mathrm{v}=$ onepage $\& \mathrm{q}=$ central $\% 2$ 0obesity\%20correlates\%20with\%20an\%20i ncreased\%20incidence\%20of\%20nash\%2Fn afld\&f $=$ false

10. Johnston DE. University of New Mexico School of Medicine. New Mexico Am Fam Physician. 1999. Avaiable from: URL: http://www.aafp.org/afp/1999/0415/p2223.h tml. 